\section{Water Research in Britain}

In a written answer to a question in the House of Commons on March 20 regarding Department of Scientific and Industrial Research grants for research on the utilization and conservation of water supplies, the Parliamentary Secretary for Science, Mr. D. Freeth, said that direct expenditure in such research could not be separated precisely from that which had an indirect bearing on the subject. The best estimates of current expenditure (1960-61) by the Department and co-operative research associations were: Geological Survey and Museum, £32,350; Hydraulics Research Station, £93,100; Water Pollution Research Laboratory, $£ 148,650$; British Coke Research Association, £18,750; British Leather Manufacturers Research Association, £6,800; British Paper and Board Industries Research Association, $£ 9,500$; Water Research Association, £35,000; current grants to universities for special research work, $£ 11,000$.

\section{Students Awards in Scotland}

IN a witten answer in the House of Commons on March 28, the Secretary of State for Scotland, Mr. J. S. Maclay, said that, with the agreement of the local authority associations, from next October awards would be made by the Scottish Education Department to full-time university students, students training as teachors and students taking advanced full-time or sandwich courses at other establishments. Although the education authorities would no longer make the awards, their local officers would assist the Department by interviewing students and making local inquiries when questions of special difficulty arose, and they would be responsible for advising young people in their area as to facilities available for further education. They would continue to award bursaries to other further education students and to school pupils. There will be standard maintenance allowances for students to whom the Scottish Educa. tion Department made awards at the rate fixed for the university or college which the student actually attended. These rates have been fixed on an interim basis as announced on December 19, and it is intended to undertake a comprehensive review of the rates during the coming year.

\section{The Match-making Industry in Britain}

To mark their hundredth anniversary, the wellknown match-making firm of Bryant and May has issued an attractive booklet which describes not only the history of the company but also changes in the way matches have been made over the years. Matches were invented in 1827 by an Englishman named John Walker, whose substances were: potassium chlorate, sulphide of antimony and gum arabic. A piece of fine sandpaper was included in each box. Herbert Spencer called this invention the greatest boon and blessing to come to mankind in the nineteenth century. Match-making materials have varied little since the time of the first British patent granted to Francis May in 1855. The head of the 'strike-anywhere' match contains chlorate of potash (to provide the oxygen) and sesquisulphide of phosphorus, while a safety-head match consists mainly of chlorate of potash and sulphur, providing flame when rubbed against the amorphous phosphorus on the side of the box. The materials in both heads are bound together by special Scottish glue. The sticks are treated with paraffin to help them burn and ammonium phosphate to prevent smouldering. A feature of the match industry is the curious way certain districts in Britain will buy certain types of matches -only the box is different - and no other.

\section{U.S. Federal Expenditure on Science}

IN its ninth issue of Federal Funds for Science, the National Science Foundation analyses Federal expenditure on scientific research and development in the fiscal years 1959-61, during which period the total increased from 6,200 million dollars to 7,700 million dollars in 1960 and an estimated 8,200 million dollars in 1961; the corresponding obligations are 7,400, 8,600 and 8,500 million dollars, respectively, and of the last, about 10 per cent is for basic research (Surveys of Science Resources Series. Pp. iii +89 . Washington, D.C. : Government Printing Office, 1960. 50 cents). As in 1960, some 90 per cent of the total is expected to be administered by the Department of Defense, the Atomic Energy Commission and the National Aeronautics and Space Administration. 44 per cent of Federal obligations for basic research in 1960 were allocated to educational institutions, 30 per cent to Federal agencies and 14 per cent to profit organizations. Obligations to the National Science Foundation increased by one-third in 1960 to 72 million dollars, and an increase to 84 million dollars is anticipated in 1961. Of obligations totalling about 1,900 million dollars for basic and applied research in 1960, the physical sciences, including mathematics and engineering, accounted for 56 per cent, the biological sciences for 27 per cent and the remaining 17 per cent went to the psychological, social and other seiences. Of this 'other sciences', about 85 per cent is accounted for by research into the space sciences administered by the National Aeronautics and Space Administration. Trends in expenditure and obligations over the period 1940-61 are also analysed in the report.

\section{The Australian Scientist}

Ir is a fair wind that finds among the farrago of scientific journals one that is devoted to science in its broadest fields. The tendeney in the past has been for most countries to produce at some time or other a scientific showpiece, and it was logical that in time Australian seientists should wish to make their contribution. The Australian Scientist, a new journal (1, No. 1 (February 1961). Pp. 70. Subscription rates (1 year): Australia, Fiji, New Guinea, New Zealand fA4 4s. 0d.; Commonwealth countries (excluding the above) fSterling $£ 3$ 12s. 6d.; NonCommonwealth countries £Sterling $£ 45 s .0 d$. Liechhardt, Sydney: Tasman Productions, 9-23 Upward Street, 1961), does much mole than just act as a showroom for Australian science, and represents a major contribution to the cornmunication of science in general. As would be expected from the strong editorial board, consisting of Prof. A. A. Abbie, Prof. S. T. Butler, Dr. A. S. Fraser, Prof. R. J. W. Le Fevre, Prof. H. Messel, Sir Mark Oliphant, Prof. R. N. Robertson, Prof. R. H. Thorp and Sir Samuel Wadham, the first issue sets a very high standard of material and presentation. The pattern of the journal follows the traditional form of many of the world's established journals, but rather than just represent science it also acts as a spokesman; and it is planned that a section of letters to the editor will commence as soon as practicable. 